\title{
To the New Leonardo Galleries
}

\section{Claudio Giorgione}

\section{(2) OpenEdition}

\section{Journals}

Electronic version

URL: http://journals.openedition.org/artefact/5942

DOI: $10.4000 /$ artefact.5942

ISSN: 2606-9245

\section{Publisher:}

Association Artefact. Techniques histoire et sciences humaines, Presses universitaires du Midi

\section{Printed version}

Date of publication: 15 July 2020

Number of pages: $273-277$

ISBN: 978-2-8107-0691-4

ISSN: 2273-0753

\section{Electronic reference}

Claudio Giorgione, «To the New Leonardo Galleries », Artefact [Online], 12 | 2020, Online since 21 December 2020, connection on 23 December 2020. URL : http://journals.openedition.org/artefact/ 5942 ; DOI : https://doi.org/10.4000/artefact.5942

\section{$\Theta \oplus \Theta \Theta$}

Artefact, Techniques, histoire et sciences humaines est mise à disposition selon les termes de la Licence Creative Commons Attribution - Pas d'Utilisation Commerciale - Pas de Modification 4.0 International. 


\section{To the New Leonardo Galleries}

I

n 1953, the Museum was inaugurated with a major exhibition on "Science and Technology of Leonardo da Vinci," which soon evolved into a permanent gallery. ${ }^{1}$ Guido $\mathrm{Ucelli}^{2}$, the Museum founder, entitled the museum to Leonardo da Vinci (Vinci 1452 - Amboise 1519), who is still today a global cultural icon, as well a symbol of curiosity and of interdisciplinary knowledge. His ability to observe nature and the work of others is a fundamental element of his relevance for modern times. His work, which calls upon drawing as a method of observation and study, constitutes a precious legacy for our society, inspiring an approach to knowledge capable of overcoming the traditional gap between scientific knowledge and humanistic culture. For over 60 years the Museum has been telling visitors from all over the world about this extraordinary figure. The upcoming celebrations of Leonardo's birth anniversary, has resulted in an intensification of research, placing Leonardo at the center of a path of study and rediscovery to reconstruct his role with respect to the Museum.

This was the starting point of the total redesign of the Museum's historic exhibition dedicated to Leonardo, opened in December 2019. The new galleries curatorial project is the result of a decade of study and reflection on the history and on the collections of the museum. It combines it with the latest scientific research, to better present the work of Leonardo, as

1. About the history of the collection see: Giorgione, 2009, p. 16-31; Giorgione, 2015; Giorgione 2019, p. 59-61.

2. Guido Ucelli (Piacenza 1881, Milano 1964), an engineer, industrialist and humanist. As the CEO of the Riva \& Calzoni Company, he contributed in the 20's to the recovery of the ancient roman ships from the lake of Nemi, near Rome. In the 30's he started to support the establishment of an Industrial Museum in Milan and he succeeded in his mission after WW2. The National Museum of Science and technology in Milan opened on February $15^{\text {th }} 1953$, as the final act of the celebrations for the fifth centenary of Leonardo da Vinci's birth.

99 Claudio Giorgione, « To the New Leonardo Galleries », Artefact, 12, 2020, p. 273-277. 
a humanist, an engineer, and an investigator of Nature. Thus, it reveals a more holistic view of the figure of Leonardo, away from the myth of the brilliant inventor, to be better understood within his own time and context, including places he visited and people he met during his lifetime. ${ }^{3}$

This enables us to "Get closer" to the truest Leonardo, and discover his thoughts and thinking process which are truly unique and innovative and can still inspire us today such as the careful observation of nature, the use of drawing as tools for understanding and communication, the ability to connect ideas in a flexible and multifaceted way. The precious collaboration of more than 70 cultural institutions $s^{4}$ from all around the world has allowed to create an iconographic itinerary of unique richness, making it possible to reveal Leonardo's figure and work fully and completely, and not merely as that of an engineer or technologist. The experience and vision of museographer François Confino ${ }^{5}$ and of the LLTT Studio ${ }^{6}$ have contributed to the display of more than 170 works: early models, ancient books, historical facsimiles, frescoes, casts, reliefs, and decorations. The historical models built in 1953 including the study and interpretation of Leonard's drawings and manuscripts are still at the center of the display but enhanced by many other works, and thus able to better tell and illustrate the relationship between Leonardo and the historical context of his time.

The Museum's architectural structure-an Olivetan monastery from the 16th century - has required a momentous task of selection and layout of historical objects, some of considerable size. This necessitated continual discussions among curator, staff and museographer to determine the optimal itinerary for the exhibition. The set-up was defined as one to present numerous and varied works that would give an account of Leonardo's

\footnotetext{
3. Two fundamental steps in the process of study and research have been carried out in 2019 . The Exhibition (and related catalogue) Leonardo da Vinci. La Scienza prima della Scienza held at Scuderie del Quirinale in Rome from March 13th to June 30th 2019 and the volume Leonardo 1939. La costruzione del mito (Beretta, Canadelli and Giorgione dir., 2019).

4. The four main scientific partners of the new Leonardo Galleries are: Musei Reali, Turin, Royal Collection Trust, Windsor, Soprintendenza Castello, Milan and Institut de France, Paris

5. Francois Confino (Geneva 1945) is a Swiss - French architect and museographer, who has been working for international project for many Museums in the world. Among them, the National Museum of Cinema and National Automobile Museum in Turin in 2000 and 2011, the Charlie Chaplin Museum in Vevey in 2015.

6. LLTT Studio, Marida Cravetto and Federica Pagella, based in Turin.
} 
prolific and multidisciplinary corpus, starting with the actual surface-area requirements, but also, and above all, on the basis of a coherent succession and sequencing of artefacts and contents. Within the wide-ranging proposals of the project, various skills and disciplinary fields converge along the itinerary, making the works themselves the narrators of a story, of a cultural message.

The new exhibition layout presents the works of the collection in accordance with a precise scientific program, with careful attention to the layout of artefacts and presenting the information to the public. Alongside this more "classical" approach to the exhibition layout, audiovisual installations are proposed in some rooms, in synchronization with the ambient lighting systems, showcasing objects in specific contexts, thereby enhancing their aesthetic and communicative effect, being part of the curatorial project and not just entertainment.

The visit to the Leonardo da Vinci Galleries offers a circular path connecting the large central corridor to lateral spaces. The sections present the different fields of Leonardo's study, research and creations. The themes treated include: training in Verrocchio's workshop and Leonardo's interests for machines and mechanisms from the Florence of Tuscan engineers; drawing as a method of investigation, understanding and communication across diverse branches of knowledge; military engineering projects and the fantastic war machines of medieval tradition; technical solutions to improve work and production tools designed during Leonardo's first sojourn in Milan; studies on flight, with the anatomy of birds as a point of departure; surveys of the Lombard territory and waterways; Leonardo's contributions to the debate on architecture; Leonardo's influence in Lombard painting of the late Renaissance; and finally his later thoughts reflecting on the idea of the cosmos being governed by universal laws.

Some sections highlight the new approach in storytelling. The first room, which is dedicated to everyday life during Leonardo's time, was transformed into a model street of an ideal city of the Renaissance thanks to the large stage scenery images painted along two walls, vividly immersing the visitor in the context (Fig. XXXVII, colour plates).

The importance of the study of nature, in room two, has been developed thanks to setup of two "archives of nature," real Wunderkammer displaying naturalia (fossils, stuffed and anatomical specimens, insects) on permanent 
loan from the Natural Museum of University of Pavia (Fig. XXXVIII, colour plates).

The theme of the art of war develops through the central gallery, with large synchronized projections on both walls setting into motion a medley of Leonardo's battle-themed drawings (Fig. XXXIX, colour plates). The slow movements animating whole or partial figures create a large vibrantly dynamic fresco serving as backdrop for models of Leonardo's ballistic and military studies. At the center of the room stands the giant crossbow-the most representative and suggestive work — situated within a diorama depicting battle scenes the visitor can admire through special oculi fashioned into the exhibitor walls.

The itinerary concludes with a totally immersive installation of great eloquence. It was created using multiple projections of Leonardo's drawings of deluges, from his latest period, which formulate his wide-ranging theories on nature (Fig. XL, colour plates). In this room the visitor experiences the sensations of being immersed in swirling motions and lifted upon the winds. These are extrapolations based on the emotional empathy conveyed by Leonardo's drawings, where the natural elements are translations of the movements of the soul resulting from the inevitability of certain natural phenomena and from the impossibility to know or control them.

The exhibition setup and the scenographic apparatus enable to locate Leonardo's work within the context of his era, but also to transmit the universality of his studies and the results he achieved through investigation and research. Leonardo was a man of his time, attentive to all fields of knowledge and capable of identifying their interconnections and synergies, but also a man of our time, for the transversal nature of his approach to the world and for his critical mind.

Claudio Giorgione

Curator, Museo Nazionale Scienza e della Tecnologia "Leonardo da Vinci" 
To the New Leonardo Galleries

\section{Bibliography}

Beretta Marco, Canadelli Elena and Giorgione Claudio (dir.), "Leonardo 1939. La costruzione del mito”, Editrice Bibliografica, Milano, 2019.

Giorgione Claudio, Leonardo da Vinci. The Models Collection, Fondazione Museo L. da Vinci, Milan, 2009.

Giorgione Claudio, "The birth of a collection in Milan: from the Leonardo Exhibition of 1939 to the opening of the National Museum of Science and Technology in 1953", Issue 04, Autumn 2015, Science Museum Group Journal, 2015 [http://dx.doi.org/10.15180/150404].

Giorgione Claudio (dir.), Leonardo da Vinci. La Scienza prima della Scienza, Arte'm, Napoli, 2019. 